\title{
An overview of the health status of Syrian refugee children in a tertiary hospital in Turkey
}

\author{
Ibrahim Hakan Bucak, Habip Almis, Samet Benli, Mehmet Turgut \\ Department of Pediatrics, School of Medicine, Adiyaman University, Adiyaman, Turkey
}

\begin{tabular}{|c|}
\hline Access this article online \\
\hline Website: www.avicennajmed.com \\
\hline DOI: 10.4103/ajm.AJM_17_17 \\
\hline Quick Response Code: \\
\hline
\end{tabular}

\section{ABSTRACT}

Objective: Migration is a problem affecting all family members, but particularly children. Child refugees are the highest risk group for the health systems of receiving countries. We investigated the health of 104 Syrian child refugees presenting to a tertiary hospital in Turkey. Settings and Design: A retrospective study was conducted in the pediatric clinic. Materials and Methods: The medical files of Syrian refugee children (0-18 years) presenting to Adiyaman University Hospital, Pediatric Clinic between 01 and 30 November 2015, were investigated. Demographic data, body measurements, and laboratory results obtained from patients' medical records were evaluated. Results: Mean age of patients was $53.5 \pm 49.6$ (2-198) months; 63 were male and 41 were female. Seventy-two patients $(69.2 \%)$ were under 5 years of age. Weight in 20 patients $(19.2 \%)$, height in $33(31.7 \%)$, head circumference in $2(1.9 \%)$, and body mass index in $7(6.7 \%)$ were below the third percentile. All patients with body weight below the third percentile had chronic malnutrition. Anemia was present in $35(50 \%)$ of the 70 patients for whom complete blood count data were available. Conclusion: Health workers involved with Syrian refugee children must consider the two preventable conditions; malnutrition and anemia.

Key words: Anemia, children, refugee, short stature, undernutrition

\section{INTRODUCTION}

Syrian refugee children are without a doubt the group worst affected by the civil war in that country. The health systems of Turkey, Lebanon, Jordan, and other regional countries are working above capacity due to the daily growing numbers of Syrian refugees. Children under the age of 5 years are the age group with the highest death rates among the populations being forced to migrate. ${ }^{[1,2]}$ Therefore, when providing health services for refugees, the pediatric age group (and particularly children under the age of five) need to be evaluated with particular care. Although it is not easy to erase the effects of the war, the Republic of Turkey is meeting the needs of Syrian refugee children inside and outside the refugee camps and also providing the highest level of health and education services. ${ }^{[3]}$

Address for correspondence: Dr. Ibrahim Hakan Bucak, Altınşehir Neighborhood, Uygur Site, G-Bloc No: 32,

Adiyaman 02040, Turkey.

E-mail: ihbucak@hotmail.com

\section{Objectives}

The purpose of this study was to evaluate the health status of Syrian refugee children presenting to a tertiary hospital in Turkey.

\section{MATERIALS AND METHODS}

The medical files of Syrian refugee children (0-18 years) presenting to our hospital pediatric clinic between 1 and 30 November 2015, were investigated retrospectively. Age (months), sex (female, male), weight (kilograms) and weight percentile (\%), height $(\mathrm{cm})$ and height

This is an open access article distributed under the terms of the Creative Commons Attribution-NonCommercial-ShareAlike 3.0 License, which allows others to remix, tweak, and build upon the work non-commercially, as long as the author is credited and the new creations are licensed under the identical terms.

For reprints contact: reprints@medknow.com

Cite this article as: Bucak $\mathrm{IH}$, Almis $\mathrm{H}$, Benli S, Turgut M. An overview of the health status of Syrian refugee children in a tertiary hospital in Turkey. Avicenna J Med 2017;7:110-4. 
percentile (\%), and head circumference $(\mathrm{cm})$ in children aged under 36 months), body mass index (BMI) and BMI percentile, diagnosis code (ICD: International Statistical Classification of Diseases and Related Health Problems) and chronic diseases if applicable were recorded from the files. Laboratory tests recorded in the file system (complete blood count $[\mathrm{CBC}]$, iron, iron-binding capacity, ferritin, Vitamin B12, folic acid, magnesium, 25 hydroxyvitamin D, parathormone, tissue transglutaminase $\operatorname{Ig} \mathrm{A}$ and $\operatorname{IgG}$ ) were evaluated.

The World Health Organization (WHO) growth curves were used in evaluating weight, height, head circumference, and BMI percentiles. ${ }^{[4,5]}$ However, since there are no percentile curves for weight for children over 10-year-old among the WHO growth curves, the weight percentiles for children in that age group were assessed by comparison with weight percentile curves for Turkish children ${ }^{[6]}$ The Waterlow classification was used to differentiate acute/chronic malnutrition in cases with weight below the third percentile. ${ }^{[7]}$ Based on that classification, subjects with height for age below 95\% were regarded as having chronic malnutrition. The Gomez classification was also used to evaluate malnutrition. ${ }^{[8]}$ Under this classification, weight for age $>90 \%$ is regarded as normal, $75 \%-89 \%$ as mild malnutrition ( $1^{\text {st }}$ degree), $60 \%-74 \%$ as moderate malnutrition ( $2^{\text {nd }}$ degree $)$, and $<60 \%$ as severe malnutrition ( $3^{\text {rd }}$ degree).

Reference intervals for our hospital laboratory were used in evaluating patients' laboratory results. However, the hemoglobin for age scale was used to assess patients' hemoglobin levels. ${ }^{[9]}$ If patients' hemoglobin for age values were below the minimum threshold on the scale, those patients were regarded as anemic.

Statistical Package for the Social Sciences version 21 for Windows (IBM, Armonk, NY, USA) software was used for statistical analysis. Qualitative data were expressed as mean plus standard deviation (SD) and quantitative data as prevalence and percentage values.

Approval for the study was granted by the Adiyaman University Medical Faculty Biomedical Research Ethical Committee (No. 2016/3-2).

\section{RESULTS}

One hundred four patients, 63 (60.6\%) male and 41 (39.4\%) female, with a mean age of $53.5 \pm 49.6(2-198)$ months were included in the study. In terms of age distribution, $32(30.8 \%)$ patients were older than 60 months [Table 1].
Examination of ICD codes revealed that only 9 (8.7\%) had received routine pediatric examination diagnoses, the most common being acute infectious diseases (such as acute diarrhea and gastroenteritis, acute bronchitis and acute pharyngitis) [Table 2]. In the light of data from patients' records, 87 (83.7\%) patients had no chronic disease, while of the other 17 (16.3\%); 7 (6.7\%) were diagnosed with cerebral palsy, 5 (4.8\%) with epilepsy, 4 (3.8\%) with beta thalassemia major, and one patient each (1\%) with diabetes mellitus, thalassemia carriage, and magnesium deficiency.

In terms of weight, height, BMI, and head circumferences, weight was below the third percentile in $20(19.2 \%)$ patients, height in $33(31.7 \%)$, BMI in 7 (6.7\%) and head circumference in 2 (1.9\%) [Figure 1]. All 20 patients with weight below the third percentile had height for age values $<95 \%$ according to the Waterlow classification and were all therefore regarded as having chronic malnutrition. When the Gomez classification (weight for age) was applied, 9 (45\%) of these patients were in the mild ( $1^{\text {st }}$ degree) malnutrition category, $8(40 \%)$ in the moderate ( $2^{\text {nd }}$ degree $)$ malnutrition category, and $3(15 \%)$ in the severe ( $3^{\text {rd }}$ degree) malnutrition category.

The 20 patients with a weight below the third percentile were also below the third percentile in terms of height. Chronic malnutrition was determined in 20 (60.7\%) of the 33 cases in which we observed short stature, and this may account for that condition. Epilepsy was determined in a further $2(6 \%)$ patients, magnesium deficiency in $1(3 \%)$, iron deficiency in $1(3 \%)$ and growth retardation in $1(3 \%)$, and although these may not account for short stature they nevertheless provide scope for interpretation. However, no cause of short stature could be identified in the other 8 cases. Subjects below the third percentile in terms of weight, height, and BMI are shown in Table 2.

\begin{tabular}{lc}
\hline \multicolumn{2}{l}{ Table I: Patients' demographic data and body measurements } \\
\hline Sex & $\boldsymbol{n}(\%)$ \\
Male & $63(60.6)$ \\
Female & $41(39.4)$ \\
Age (months) & \\
$0-12$ & $18(17.3)$ \\
I3-36 & $36(34.6)$ \\
$37-60$ & $18(17.3)$ \\
$61-120$ & $19(18.3)$ \\
$>129$ & $13(12.5)$ \\
\hline & Mean $\pm S D($ minimum-maximum) \\
\hline Weight (kg) & $16.1 \pm 9.8(5-52)$ \\
Height (cm) & $96 \pm 25(56-161)$ \\
Head circumference (cm) & $45.9 \pm 2.5(39-51)$ \\
BMI & $16.1 \pm 1.79(12-22)$ \\
\hline BMI: Body mass index, SD: Standard deviation
\end{tabular}


Examination of laboratory results showed that blood results were only available for some patients, not all [Table 3]. Anemia was one noteworthy finding based on the $\mathrm{CBC}$ results, being observed in 35 (50\%) of the patients for whom such results were available. Iron deficiency was determined in $22(62.8 \%)$ of the 35 patients with anemia and Vitamin B12 deficiency in 5 (14.2\%). In addition, four patients had beta thalassemia major, and one was a thalassemia carriage. The cause of anemia was, therefore, uncertain in only $3(8.5 \%)$ of the patients with anemia. Mean ferritin level in the patients with beta-thalassemia major was $617 \mathrm{ng} / \mathrm{ml}$ and all these patients used iron chelators.

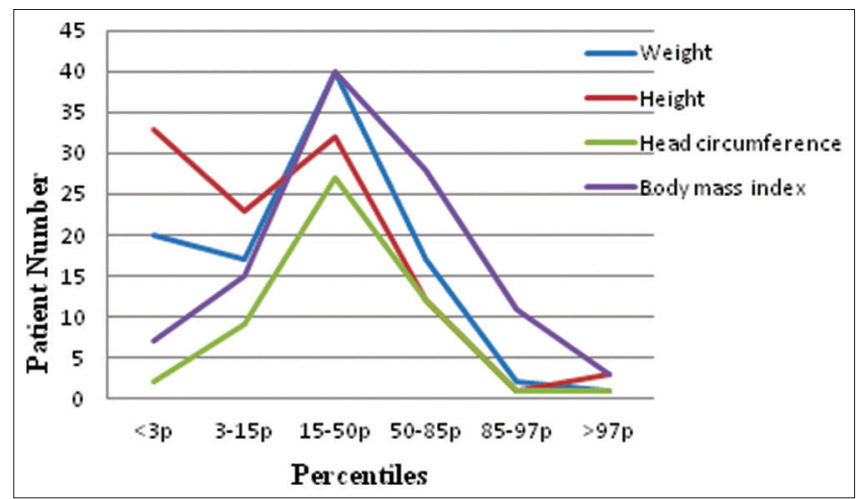

Figure 1: Percentile distributions of weight, height, bead circumference and body mass index

\section{DISCUSSION}

Turkey has admitted Syrian refugees since 2012, and a refugee camp has been established in our own province. According to United Nations High Commission for Refugees data for 2016, the number of Syrian refugees in countries neighboring to Syria is currently $4,840,555 .{ }^{[10]}$ The number of Syrian refugees in Turkey is known from official figures to be much larger than the number in other regional countries (total number 2,743,497 [56.6\%]). According to official data, $54.2 \%$ of Syrian refugees in Turkey are below the age of 18 , and $19.9 \%$ are below the age of five. ${ }^{[11]}$ The large number of refugees of childhood age means that even greater care must be directed toward them within the health system. According to a report by Escobio et al. 25\% of refugees in the Balkan region presenting for medical assistance (considering adult and child patients together) were children aged under five. ${ }^{[12]}$ Although only Syrian refugee children were evaluated in our study, $69.2 \%$ of patients were children under 5 -year-old. The health risks of patients aged under five must be anticipated in advance, and precautionary measures must be adopted accordingly.

Doocy et al. reported that Syrian refugees presenting to hospital did so due to respiratory tract diseases, fever, diarrhea, skin problems, and wounds. ${ }^{[1]}$ Beldjebel investigated

\begin{tabular}{|c|c|c|c|c|c|}
\hline & \multirow{2}{*}{$\begin{array}{l}\text { Patient numbers } \\
\text { by diagnosis, } n \text { (\%) }\end{array}$} & \multicolumn{4}{|c|}{ Distribution of patients beneath the third percentile by diagnosis } \\
\hline & & Weight & Height & BMI & Head circumference \\
\hline A09: Diarrhea and gastroenteritis & $14(13.5)$ & I & 4 & & \\
\hline J20:Acute bronchitis & $13(12.5)$ & 4 & 3 & 2 & \\
\hline J02:Acute pharyngitis & $9(8.7)$ & 3 & 3 & I & \\
\hline Z00.I: Routine child health examination & $9(8.7)$ & & I & & \\
\hline J03:Acute tonsillitis & $7(6.7)$ & & & & \\
\hline E45: Growth retardation & $6(5.8)$ & 5 & 6 & 2 & 2 \\
\hline N39: Urinary system infection & $6(5.8)$ & I & I & & \\
\hline G40: Epilepsy & $5(4.8)$ & & 2 & & \\
\hline T78.4:Allergy, unidentified & $4(3.8)$ & I & 2 & I & \\
\hline D56.I: Beta thalassemia & $4(3.8)$ & i & 2 & & \\
\hline L30.9: Dermatitis, unidentified & $3(2.9)$ & & I & & \\
\hline G80: Cerebral palsy & $3(2.9)$ & 2 & 2 & & \\
\hline F98: Nonorganic enuresis & $3(2.9)$ & & & & \\
\hline J06:Acute upper respiratory tract infection & $3(2.9)$ & & & & \\
\hline D64.9:Anemia, unidentified & $2(1.9)$ & I & I & & \\
\hline L04:Acute lymphadenitis & $2(1.9)$ & & & & \\
\hline JI8: Pneumonia, unidentified organisms & $2(1.9)$ & I & I & I & \\
\hline R26: Gait and movement anomalies & $2(1.9)$ & & & & \\
\hline E61.2: Magnesium deficiency & $1(1)^{\prime}$ & & I & & \\
\hline J30.4:Allergic rhinitis, unidentified & $\mathrm{I}(\mathrm{I})$ & & I & & \\
\hline Q53: Undescended testis & $I(I)$ & & & & \\
\hline K40: Inguinal hernia & $\mathrm{I}(\mathrm{I})$ & & & & \\
\hline R47: Speech disorders & $\mathrm{I}(\mathrm{I})$ & & I & & \\
\hline BI5:Acute hepatitis A & $I(I)$ & & & & \\
\hline D50: Iron deficiency anemia & $I(I)$ & & I & & \\
\hline Total patient number & 104 & 20 & 33 & 8 & 2 \\
\hline
\end{tabular}




\begin{tabular}{|c|c|c|c|}
\hline Patient number & Laboratory parameter & Mean士SD (minimum-maximum) & Normal range \\
\hline \multirow[t]{6}{*}{70} & White blood cell & $10,146.9 \pm 3102(4 \mid 00-18,900)$ & 3.7-I0.I $(\mathrm{K} / \mu \mathrm{L})$ \\
\hline & Hemoglobin & $11.2 \pm 1.66(6-15)$ & I I.5- $14.2(\mathrm{~g} / \mathrm{dL})$ \\
\hline & Hematocrit & $34.1 \pm 4.58(19-42)$ & $35 \%-50 \%$ \\
\hline & Mean corpuscular volume & $75.1 \pm 8.31(52-100)$ & $80-95(f \mathrm{~L})$ \\
\hline & Mean platelet volume & $8.11 \pm 1.3(5-12)$ & $6.9-10.6$ \\
\hline & Platelet count & $344,596 \pm|38,3| 3(56,200-829,000)$ & $150-450(\mathrm{~K} / \mu \mathrm{L})$ \\
\hline 35 & Iron & $45.2 \pm 27.4(10-112)$ & $47-169(\mu \mathrm{g} / \mathrm{dL})$ \\
\hline 35 & Iron-binding capacity & $3 \mid I \pm 84.7(\mid 57-463)$ & $150-300(\mu \mathrm{g} / \mathrm{dL})$ \\
\hline 23 & Ferritin & $134.6 \pm 232.8(6-788)$ & $23-336(\mathrm{ng} / \mathrm{mL})$ \\
\hline 9 & Vitamin $\mathrm{B} / 2$ & $211.1 \pm 138.2(63-40 I)$ & $|80-9| 4(\mathrm{pg} / \mathrm{mL})$ \\
\hline 7 & Folic acid & $|3.9 \pm 5.8|(6-23)$ & 5.9-24.8 (ng/mL) \\
\hline 6 & Vitamin D & $38.8 \pm 29.1(16-77)$ & 20-32 (ng/mL) \\
\hline 3 & Parathormone & $17.4 \pm \mid 4.9(9-35)$ & $15-65(\mathrm{pg} / \mathrm{mL})$ \\
\hline 8 & Tissue transglutaminase $\lg \mathrm{A}$ & I: Positive, 7: Negative & \\
\hline 9 & Tissue transglutaminase $\lg G$ & I: Positive, 8: Negative & \\
\hline 1 & Magnesium & 1.5 & $1.9-2.5(\mathrm{mg} / \mathrm{dL})$ \\
\hline
\end{tabular}

the reasons for presentation to clinics by Syrian and Iraqi refugees living in Lebanon and reported that $90 \%$ of children presented due to infectious diseases, with gastrointestinal infections being the most common. ${ }^{[13]}$ Tahirbegolli et al. showed that respiratory system diseases were most common diagnosis of Syrian refugees (age between 7 and 34). ${ }^{[14]}$ In this study, and in agreement with the literature, acute infectious diseases were also the most common cause of presentation. It may be expected that refugees will affect the prevalence of diseases in the countries in which they settle, and studies have reported that the prevalence of diseases such as measles and cutaneous leishmaniasis, which are rarely seen in Turkey, has increased. ${ }^{[15]}$ In addition, the existence in Syria of poliovirus, which has been eradicated from Turkey, and the possibility of it being brought to Turkey by Syrian refugees must not be forgotten. ${ }^{[16]}$ Vaccination programs are being implemented for Syrian refugee children for diseases that can be prevented by inoculation, such as polio. One study of Syrian refugee children who had settled in Germany revealed that $11 \%$ of 488 children had been diagnosed with active tuberculosis and $9 \%$ with chronic hepatitis $\mathrm{B}$ or $\mathrm{C}$, which are noteworthy figures. ${ }^{[17]} \mathrm{We}$ encountered no record concerning tuberculosis or chronic hepatitis in the children in our study. In the light of previous studies, we must be more on our guard against contagious diseases such as tuberculosis.

Short stature is defined as being two SDs for age and sex or below the third percentile. ${ }^{[18]}$ Causes such as familial and constitutional factors, nutritional deficiency, chronic systemic diseases, endocrinological disorders, and bone dysplasias must be considered when evaluating short stature. One striking finding of this study concerns short stature. Short stature was present in 33 patients although only $6(5.8 \%)$ patients were diagnosed with growth retardation in the record system. This shows that patients presented due to acute infectious diseases but that growth retardation was overlooked. Chronic malnutrition being identified in 20 of the cases of short stature in this study is particularly significant because chronic malnutrition is a preventable cause. We were unable to draw any conclusions concerning the cause of short stature in eight of the other 13 cases. In addition, it is not always possible to access information that can be of use in evaluating short stature, such as data concerning Syrian refugee children's births (such as prematurity and low birth weight), height of parents, children's previous anthropometric measurements, previous diseases, and drugs used. Although the data we record onto our file system is useful at repeat examinations in our hospital, recording such data onto a common data bank will greatly facilitate the monitoring of refugee patients.

Anemia being determined in 35 (50\%) of the 70 patients undergoing $\mathrm{CBC}$ is another particularly striking finding. The most common cause of anemia is iron deficiency. It is also noteworthy that Vitamin B12 deficiency was observed in $5(14.2 \%)$ patients. Both iron deficiency anemia and Vitamin B12 deficiency anemia are preventable causes, and therefore highly important. According to the WHO, the prevalence of anemia in industrialized countries is 39\% at age $0-4$ and $48.1 \%$ at age $0-14 .{ }^{[19]}$ The most common cause of childhood anemia is iron deficiency. ${ }^{[20]}$ There are no data in the literature concerning the prevalence of anemia in Syrian refugee children, but the prevalence of anemia determined by us was slightly higher than the WHO figures. We think that "provision of iron support and the prevention of Vitamin B12 deficiency" should be the two principal headings to be considered in health planning involving Syrian refugees. 


\section{CONCLUSION}

Turkey has made considerable efforts to provide free and direct tertiary access to healthcare for Syrian refugee children, most of whom present to pediatricians only when an acute symptom occurs. We recommend that every refugee child should be scanned for malnutrition and anemia and that iron, Vitamin B12 or defined nutritional support should be provided, if required, to preserve the health status of such individuals.

\section{Financial support and sponsorship}

This study was granted by the Adiyaman University Medical Faculty Biomedical Research Ethical Committee (No. 2016/3-2).

\section{Conflicts of interest}

There are no conflicts of interest.

\section{REFERENCES}

1. Doocy S, Lyles E, Akhu-Zaheya L, Burton A, Weiss W. Health service utilization and access to medicines among Syrian refugee children in Jordan. Int J Health Plann Manage 2016;31:97-112.

2. Guha-Sapir D, Panhuis WG. Conflict-related mortality: An analysis of 37 datasets. Disasters 2004;28:418-28.

3. The UN Refugee Agency. Syrian Refugees in Turkey Frequently Asked Questions. Available from: http://www.unhcr.org/turkey/uploads/root/ frequently_asked_questions.pdf. [Last cited on $2016 \mathrm{Jul} 20$ ].

4. World Health Organization. The WHO Child Growth Standards. Available from: http://www.who.int/childgrowth/standards/en/. [Last cited on $2016 \mathrm{Jul} 20$ ].

5. World Health Organization. Growth Reference Data for 5-19 Years. Available from: http://www.who.int/growthref/en/. [Last cited on 2016 Jul 20].

6. Neyzi O, Bundak R, Gökçay G, Günöz H, Furman A, Darendeliler F, et al. Reference values for weight, height, head circumference, and body mass index in Turkish children. J Clin Res Pediatr Endocrinol 2015;7:280-93.

7. Waterlow JC. Classification and definition of protein-calorie malnutrition. Br Med J 1972;3:566-9.

8. Altas B, Kuloglu Z. Approach to children with malnutrition. Turk J Pediatr Dis 2011;5:54-64.

9. Lerner NB. The anemias. In: Kleigman RM, Stanton BF, St Geme JW, Schor NF, Behrman RE, editors. Nelson Textbook of Pediatrics. Ch. 441 Philadelphia, PA: Elsevier Saunders Inc.; 2011.

10. Syria Regional Refugee Response. Inter-Agency Information Sharing Portal. Available from: http://www.data.unhcr.org/syrianrefugees/ regional.php. [Last cited on 2016 Jun 17].

11. Syria Regional Refugee Response. Inter-Agency Information Sharing Portal. Available from: http://www.data.unhcr.org/syrianrefugees/ country.php?id $=224$. [Last cited on 2016 Jun 17].

12. Escobio F, Echevarria J, Rubaki S, Viniczai V. Health assistance of displaced people along the Balkan route. Lancet 2015;386:2475.

13. Beldjebel I. Infectious Diseases in Refugees Coming from Syria and Iraq to Lebanon. $16^{\text {th }}$ International Congress on Infectious Diseases (ICID). Vol. 21; 2014. p. 26. Available from: http://www.dx.doi.org/10.1016/j. ijid. 2014.03.465. [Last cited on 2016 Jul 22]. [Abstracts].

14. Tahirbegolli B, Çavdar S, Çetinkaya Sümer E, Akdeniz SI, Vehid S. Outpatient admissions and hospital costs of Syrian refugees in a Turkish university hospital. Saudi Med J 2016;37:809-12.

15. Inci R, Ozturk P, Mulayim MK, Ozyurt K, Alatas ET, Inci MF. Effect of the Syrian civil war on prevalence of cutaneous leishmaniasis in Southeastern Anatolia, Turkey. Med Sci Monit 2015;21:2100-4.

16. Akil L, Ahmad HA. The recent outbreaks and reemergence of poliovirus in war and conflict-affected areas. Int J Infect Dis 2016;49:40-6.

17. Mockenhaupt FP, Barbre KA, Jensenius M, Larsen CS, Barnett ED, Stauffer W, et al. Profile of illness in Syrian refugees: A GeoSentinel analysis, 2013 to 2015. Euro Surveill 2016;21:30160.

18. Nwosu BU, Lee MM. Evaluation of short and tall stature in children. Am Fam Physician 2008;78:597-604.

19. World Health Organization. Iron Deficiency Anaemia Assessment, Prevention, and Control: A Guide for Programme Managers. Geneva, Switzerland: World Health Organization; 2001. Available from: http:// www.who.int/nutrition/publications/en/ida_assessment_prevention_ control.pdf. [Last cited on 2016 Jul 22].

20. Özdemir N. Iron deficiency anemia from diagnosis to treatment in children. Turk Pediatri Ars 2015;50:11-9. 